\title{
International Terrorism and East African sub-regionalism: Developing a Sub-regional Tourism Industry in the Face of War
}

Alfred Anangwe*

\begin{abstract}
This paper discusses both positive and negative implications of fighting international terrorism and how it impacts on trust between East African countries, peace building in the region and tourism development in East Africa.
\end{abstract}

\section{Résumé}

Cet article analyse les implications positives et négatives de la lutte contre le terrorisme international et l'impact de celle-ci sur la confiance entre les états estafricains, sur le processus de construction de la paix et le développement du tourisme en Afrique de l'Est.

\section{Introduction}

In Africa, integration within and between regions has been thought of as an alternative development strategy, especially following the failure of Structural Adjustment Programmes (SAPs). This can, however, be achieved in an environment of peaceful co-existence between and within countries in a given (sub)region. This, therefore, calls for solutions to the problems of political conflicts and international terrorism. Lack of peace in regions of Africa adversely affects industries such as tourism.

* Independent Scholar, Nairobi, Kenya. 
In the case of Africa, tourism was developed, during the colonial period and shortly after independence, as a regional industry. The development of the tourism industry in East Africa has, in the recent past, been negatively impacted by international terrorism as well as the war on terror. It is in the same vein that Professor Ali Mazrui says "war and peace exist in Africa for reasons that are not always internal to Africa. Conflicts in other parts of the world often have huge repercussions across Africa' (Mazrui 2003:8).

Africa, just like the United States, is affected by international terrorism both in terms of massive loss of lives and property as well as economic development. In terms of economic development in East Africa, there has been a slump in the tourism industry. The attack on the United States on September 1 1, 2001 epitomised the threats of international terrorism. The responses arising from this attack, collectively termed as the "War on Terror", have both positive and negative implications for efforts towards sub-regional integration in Africa in general and East Africa in particular.

Fighting international terrorism has taken many forms as well as involved many actors. The forms include militaristic and diplomatic means. Militaristic solutions to international terrorism have been applied in Afghanistan and Iraq, generating many reactions in support and opposition and all pointing towards its successes and failures. It was expected that two countries in the East African Region, Sudan and Somalia, would be militarily attacked through this method. This created a mood of fear in the region affecting tourism but also creating suspicion among countries in the region as some countries were expected to provide launch pads from which the attacks would be carried out on Sudan and Somalia. So fighting international terrorism in the Eastern African region provides two conflicting positions. On the one hand, it is a pre-requisite for economic (sub)regional development and on the other a ground for continued suspicion and therefore (sub)regional disintegration. Therefore, fighting international terrorism requires a diplomatic rather than a militaristic approach.

If the United States applied a militaristic approach then it was thought that the most appropriate ground for attacking these countries was Kenya. However, due to little success achieved in Afghanistan and Iraq through use of military, and subsequent eminent loss of international support, the United States adopted a diplomatic method towards resolving conflicts in Somalia and Sudan. Kenya, as it would have been 
used if military attacks were to be used, is playing a useful role in these diplomatic efforts.

It is this diplomatic means that I refer to as a positive result of the 'War on Terror'. This diplomatic approach, now being applied under the supervision of the Kenyan government, to find peace for the countries and the region is an important aid in fighting terrorism. This is because war creates an obscure environment within which terrorists can operate unnoticed. A stable government is important in aiding the fight against terrorism although not sufficient. Diplomatic methods of fighting terrorism now underway will go a long way in fostering good neighbourliness in the region and therefore cooperation in the development circles.

There is, however, the dark side in the fight against terrorism arising from the way Kenya is handling international terrorism through issuance of security threats that negatively impact on tourism in East Africa. The treaty that established the East African Community (EAC) demands that the issue of security be handled collectively through consultation. When Kenya seeks funds from the United States to bolster its security situation as well as compensate its economic losses resulting from terrorism, it sidelines the other two partner states, Uganda and Tanzania.

The paper discusses both positive and negative implications of fighting international terrorism and how it impacts on trust between East African countries, peace building in the region and tourism development in East Africa.

\section{Need for sub-regional integration}

In this era when Africa's development has been negatively affected through pursuit of policies advanced by the Bretton Woods institutions, mainly the World Bank and International Monetary Fund (IMF), new ways for Africa's development need to be sought and attempted. According to Uche:

International financial institutions have been extensively criticized for the inability of their programs and schemes to enhance economic development and reduce poverty in Africa. If anything, some have argued that their programs have further plunged the sub-continent into economic distress (Uche 2002:2). 
There is an increasing concern in Africa for the development of homegrown solutions to Africa's development problems as stated in the NEPAD document. This is because programmes initiated and funded from abroad have been out of touch with the circumstances unique to the African continent (Uche 2002).

The need for sub-regional integration is not new in Africa. When African countries attained independence, two schools of thought emerged with regard to integration. One school of thought, led by Nkrumah, was hinged on promoting the formation of regional entities whereas the other was bent on the formation of continental unity. The other, led by Nyerere, wanted African unity to take place one step at a time. This was based on his understanding that the diversity of the African continent required first forming regional groupings on the basis of which continental unity would be achieved.

Nkrumah was a revolutionary pan-Africanist who wanted the whole continent to unite at once because taking a slow pace would leave plenty of room for imperialism to further frustrate African unity. This led Nkrumah to de-campaign the formation of the East African Federation but without success (Okoth 1986).

Based on the examples of Europe and North America, regional and sub-regional integration creates bigger markets and enhances both trade and industry. Sub-regional cooperation leads to advantages of economies of scale, which result from both bigger markets and mobilisation of resources. It is with this understanding that Kenya, Uganda and Tanzania are working towards the formation of the East African Community. However, this process must be understood from what was/is happening in the world as a whole.

The Lomé IV (1990) trade agreement made it clear that Africa would make losses under a single European market as a result of:

1. Reduction or total elimination of the preferences given to Africa's export to the EC

2. Reductions in volumes of Africa's exports to EC due to removal of preferential treatment and competition from other regions

3. Stiffer competition for Africa's exports to the EC from other regions

4. Higher costs of imports being harmonized with EC tariffs, among others.

Consequent to the formation of the EC was the incentive to start thinking about promoting intra-regional trade and export diversification. In addition, other regional blocs in North America, such as NAFTA, were further diminishing Africa's access to export commodity markets by: 
1. Raising the average level of protectionism in advanced countries

2. Hardening of export competitiveness.

3. Substitution for Africa's commodity exports and imposing losses in terms of trade.

4. Higher costs of imports and reduced export earnings from these markets.

Regional and sub-regional integration were among the proposals for the solution of Africa's problems discussed at the Kampala Conference on Security, Stability, Development and Cooperation (CSSDCA), held in May 1991.

The Kampala forum endorsed the approach of phased continental integration with sub-regional economic groupings as the building blocs and leading to the formation of the Africa Economic Community (AEC). The Treaty Establishing the African Economic Community was signed at the OAU Summit at Abuja (Abuja Treaty) on 3 June 1991, and came into force in May 1994.

Okoth (2001) has elucidated the reasons why African countries should promote intra-regional cooperation for economic advancement as follows:

1. African countries can not hope to compete individually in the 'new' international economic system dominated by regional economic blocs.

2. The need for collective action in utilizing such resources as waterways, forests and coastal zones, and general management of environment.

3. African countries must seek to explore opportunities for beneficial cooperation with other developing and industrial countries.

In eastern Africa, prospects for sub-regional integration will be obtained from successful achievement of the East African Community (EAC). EAC forms the nucleus around which other countries in the sub-region can coalesce. Although currently comprising of Kenya, Uganda and Tanzania, other countries are already showing signs of joining the EAC. For the EAC community to thrive and attract more members, a peaceful environment is mandatory. Already, international terrorism is threatening the EAC and its growth.

\section{International Terrorism}

It is not easy to define international terrorism except from a descriptive point of view. To attempt a definition, one needs to give it a time and spatial frame. I attempt a description of International Terrorism from a post September 11 attack on the United States and the discourse this 
attack generated thereafter as well as the global action taken against real or perceived perpetrators. The description provided here is therefore that advanced by the United States and adopted by its allies in the 'War on Terror'.

International terrorism has been referred to as the $21^{\text {st }}$ century threat to civilization. It is a threat targeted at the United States or its foreign interests. When it is targeted at U.S. interests abroad, America says it is targeted at her friends. In the same vein, any efforts to fight terrorism must involve protection of U.S. friends. George Bush refers to terrorists as 'our enemies (who) want the capability to blackmail us, or to harm us, or to harm our friends' (Bush 2002).

From President Bush's statement we can define terrorism as any act of aggression, real or threatened, aimed at blackmailing or harming the United States or her friends. This makes it international as it is not targeted at U.S. but also at its allies. International terrorism goes beyond terrorists themselves, defined as people who carry out the actual threats and acts of terrorism. The definition goes further to include any support that such terrorists obtain. The support could be in the form of providing residence to or arming terrorists. The term, therefore, includes those countries which host terrorists. This is based on the fact that terrorists are groups that do not constitute states in themselves but which hide within states and/or get support from them.

As we survey the security environment, a strong link between terroristsponsoring states and the spread of Weapons of Mass Destruction becomes readily apparent. We believe that with very few exceptions, terrorist groups have not acquired and cannot acquire Weapons of Mass Destruction without the support of nation-states. Thus we are moving to end state-sponsored terror, and to expose those states that are acquiring WMD, often in violation of global non-proliferation treaties (Bolton 2002:5).

The term goes further to include both state and non-state actors as components which make international terrorism complete. In addition, it includes those states which possess dangerous weapons and are unfriendly to the United States. This is based on the argument that such states can transfer weapons to terrorists for use against the U.S. These weapons have been branded Weapons of Mass Destruction (WMD).

As we combat the threat of terrorism, we must be prepared for everescalating means of attack from weapons designed to kill far greater numbers of people and wreak havoc on our infrastructure as the United 
States works to rid the world of the terrorist threat, we must not discount the real and added danger posed by chemical, biological, and nuclear weapons falling into the hands of terrorists. Dictators in hostile states such as Iran, Iraq and North Korea already possess some WMD and are developing others. Their terrorist allies are in search of such weapons, and would waste no opportunity to use them against us (Bolton 2002:5).

Terrorists, according to this discourse, are non-state actors who need the protection and sponsorship of states. International terrorism, therefore, refers to both state and non-state actors. This broad definition of international terrorism has also broadened the fight on terrorism. In fighting international terrorism, it has become necessary to fight both the state and non-state actors. The 'War on Terror' has therefore included both attacks on state and non-state actors.

However, much of the first instances of fighting terrorism, which were militaristic, did not yield much fruit as evident in the U.S. attack on Afghanistan and Iraq. The target in Afghanistan was to capture Osama Bin Laden either dead or alive. This attack was therefore targeted at both the government, which harboured terrorists and terrorists themselves. On the other hand, the U.S. attack on Iraq was based more on the fear that Iraq was in possession of Weapons of Mass Destruction, which it would easily transfer into the hands of terrorists. The allegation that Iraq possessed WMD is proving false with consequent reactions from all over the world. The loss of the military fight on terrorism has, however, proved to be beneficial to the East African region in terms of peace-building. This benefit comes from the fact that earlier on, there was the possibility of the U.S. attacking Sudan and Somalia in the East African region. This was based on the understanding that Osama Bin Laden had at one time been hosted in Sudan and also that most of the terrorists who bombed Nairobi and Dar-es-Salaam in 1998 came through Somalia. On the other hand lack of government in Somalia, it was thought, would provide a conducive environment for thriving of terrorist cells.

The failure of the United States to find WMD in Iraq has become a blessing to Sudan's peace-building. Instead of utilising military methods, the U.S. is now promoting diplomacy. Many analysts see this as a U.S. face-saving mission. Whether face-saving or not, this gesture is good for the peaceful co-existence of countries in the East African Region which can promote integration and trade. Sub-regional or regional 
integration requires peace and trust. If the US had utilised military means, there were chances that it would have sought Kenya's aid, especially in providing military landing grounds. This would have created mistrust between Kenya and Sudan.

In fighting terrorism, the U.S. has adopted measures that will promote peace in Africa. Two such measures include diplomatic peacebuilding initiatives in Sudan as well as checking on proliferation of arms.

\section{Peace-building in Sudan}

The US is beginning to realize that stateless as well as states in conflict in Africa is not just an African problem but also a world problem because terrorist groups may find a home in such states and operate unnoticed. War torn areas are conducive environments for recruitment and training of terrorists and through which terrorists can acquire weapons. So, the US has adopted diplomatic methods towards conflict management with their support. In examining why the United States was giving Sudan a second chance, Charles Omondi makes the observation that 'the biggest obstacle to peace has been American policy which has been committed to overthrowing the government in Khartoum' (Omondi 2003:1 1). This is because Sudan at one time hosted Osama Bin Laden and there has also been the understanding that due to this sympathetic mood to Osama, Sudan could have a nuclear plant for manufacturing chemical weapons for use by terrorists. The fresh look that the US is giving Sudan climaxed when the United States Secretary of State, Collin Powell, attended the Sudan peace talks in Naivasha on 23 October, 2003.

Former US president Jimmy Carter once observed that the US policy was an obstacle to peace in Sudan by supporting the revolutionary movement rather than working for an overall peace settlement. The US was committed to overthrowing the government in Khartoum. During the Naivasha meeting in Kenya, the parties resolved the issue of security arrangement through an agreement to merge their armies and set an agenda of deliberating on the modalities of implementation such as the location of the central command.

This is in spite of outstanding issues such as wealth sharing, the status of Khartoum as the seat of government and the three disputed areas of Abyei, the Nuba Mountains and Southern Blue Nile. The reasons as to why the US is involved in finding peace in Sudan 'transcend 
US's self-proclaimed roles of defending democracy and human rights' (Omondi 2003:1 1). It has something to do with fighting terrorism. Securing peace in Sudan fits in well in this grand design. The US, for years, had blacklisted Sudan as a supporter of international terrorism.

The US could be fearing that not extending an olive branch to Sudan could further radicalize them. When terrorists attacked Kenya and Tanzania in August 1998, the US was quick to target Sudan as a possible accomplice in the acts that claimed more than 200 lives in Kenya alone (Omondi 2003:11). The pharmaceutical firm that the US attacked, however, turned out not to be the nuclear plant that it had been thought to be. President Bush is exploiting the important role that Kenya plays in regional politics to bring the Sudanese into the fold. This is a significant change in Bush's position bearing in mind that after the bombing of New York and Washington, Bush had promised to take the war to the enemy, both real and potential.

We can not put our faith in the work of tyrants, who solemnly sign nonproliferation treaties, and then systematically break them. If we wait for the threats to fully materialize, we will have waited too long we must take the battle to the enemy, disrupt his plans, and confront the worst threats before they emerge. In the world we have entered, the only path to safety is the path of action. And this nation will act (Bush 2002:2).

This gesture is beneficial for peace in the region and for regional renewal. Peace will benefit trade and investment in the region as well as promote tourism.

The other decision by the US which is going to bring peace to the region is its pledge to manage, in collaboration with Russia and other allies, proliferation of arms. This will go a long way in minimising proliferation of arms into the East African Region and thereby reduce crime and conflicts.

\section{Checking Arms Proliferation}

Many of the political conflicts that have rocked African states have been fuelled by arms proliferation, sometimes obtained through illegal trade. Many of the arms used in Africa are not manufactured in Africa. Proliferation of arms in Africa has been a result of relaxing anti-arms proliferation treaty rules and regulations. This is partly because such arms were not detrimental to the developed world. 
It was seen as an African problem without any association with the West. With international terrorism increasing at a catastrophic scale, the danger of arms falling into the hands of terrorists, who are alleged enemies of the United States, is bringing new attention to this problem.

War in certain parts of Africa is not only thriving on illegal arms proliferation but also provides an environment within which these arms can fall into the hands of terrorists.

Denying proliferators WMD technology and expertise is a central element of U.S. Non-proliferation policy. Marshalling international efforts to deny proliferators the material equipment, equipment, expertise and technology necessary to pursue Weapons of Mass Destruction (WMD) and the means to deliver them has long been a priority of the US Government. But the terrorist attacks last September 11 th and the subsequent anthrax deaths spurred a new sense of urgency in the fight against proliferation (Wolf 2002:7).

However, as a result of international terrorism and subsequently war against terrorism, the United States has renewed its commitment to enforce it. Presidents Bush and Putin agreed upon a comprehensive security strategy called New Strategic Framework during their meeting in May 2002 at the Summit in Moscow. The framework involves reducing offensive nuclear weapons, creating defensive systems that protect against missile attacks, strengthening non-proliferation and counter proliferation measures and cooperating with Russia to combat terrorism' (Bolton 2002:6).

Although America restricts the dangerous arms to include nuclear and biological there is a need to include small arms, which can be equally dangerous. The arms used in the attacks in Nairobi and Dar-EsSalaam in 1998 were not as sophisticated as the United States wants us to believe. In Africa, small arms have been the cause of many wars and subsequently many deaths. In Somalia for example, small arms have made it impossible to secure peace and elect a government. Yet it is such insecurity brought about by small arms that creates an insecure environment within which both terrorist groups can survive and even smuggle WMD.

Small arms proliferation is a problem in Africa but may also pose a threat to the ongoing 'War on Terror'. This is because of the very inse- 
curity that they help breed. As we have already discussed, insecurity breeds an environment within which terrorism can thrive and escape notice from those fighting it. Arms transfer and trafficking are having a devastating impact on Africa. The proliferation of small arms and light weapons (SALW) is no doubt a global phenomenon whose effects are most visible in Africa. These weapons make conflict more deadly and crime easier, feeding cultures of retribution and downward spirals of violence around the world. Besides taking a heavy toll on human life, small arms undermine nations' development. The widespread abuse of weapons deprives developing countries of the skills and talents of the victims of small arms. Small arms are the preferred tools of violence in most internal wars, coups, militia and gang rampages, government oppression and human rights abuses. The arms are also commonly used in domestic and transnational crime.

The US should not only worry about the potential grave dangers posed by WMD. African countries should be helped to crack down on the smuggling of small arms. Chacha contends that "the inability of the government to crack down on the arms trade led in some cases, the country to be used as a stain-ground in a wider international conflict' (Chacha 2003:11-12).

Explosives used in the bombing of the US embassy in Nairobi in 1998 and an Israel-owned hotel near Mombasa in 2002, as well as the surface-to-air rockets that would have shot down an Israeli passenger plane as it left Mombasa in 2002, are widely believed to have been smuggled into Kenya across its 'porous border' with Somalia by AlQaeda operatives or allied groups (Chacha 2003).

Despite these positive effects resulting from fighting terrorism in the World, there is the dark side which results from Kenya's handling of international terrorism on tourism in East Africa.

\section{Terrorist Bombings and Their Impact on Tourism in East Africa}

Tourism by definition and description is massive peacetime travel and therefore a security sensitive industry. In East Africa, tourism was developed on a sub-regional level and therefore, lack of peace in one country leads to a slump in tourism in the region because the region has shared infrastructure like railway lines, road networks, harbours and airports. The colonial administration contributed much towards this 
regional development of tourism. The inauguration of the East African High Commission in 1948 not only enhanced achievements over the decades of cooperation between Kenya and Uganda but also brought in Tanganyika and Zanzibar.

As a result, they shared many services essential to regional development of tourism such as East Africa Railways and Harbours, East Africa Airways Corporation, Postal and Telecommunications Services, a Customs Union, immigration issues and others. Even though Tanganyika was the first East African country to attain independence it opted to cooperate with the others under the East Africa Common Services Organization. Both the East African High Commission and East African Common Services Organization enabled East African Tours and Travel Association (EATTA) and private operators to promote tourism with official and co-operate blessings.

Even though tourism was not mentioned in the East African Treaty, the inauguration of the E.A. Community in December 1967 enhanced East Africa's development as a regional tourist destination. Consequently, there was a deliberate move towards developing tourism as a regional industry even though it was over-weighted in favour of Kenya. Even after 1965, tourists to East Africa considered this region as a tourist unit (Ouma 1970).

The EATTA did a lot of publicity of tourism whose fruitful results were evident in terms of its contribution to the GDP of Kenya, Tanganyika and Uganda during the colonial period. After independence, individual East African countries continued to promote tourism in their respective countries, but with a regional touch. In 1968, tourism was number one, two and six respectively in Kenya, Uganda and Tanzania as earner of foreign exchange. In Kenya alone, tourism earned more foreign exchange than coffee, tea or any other crop (Ouma 1970).

However, terrorist bombings in Nairobi which started in 1998 began to undermine achievements made in the tourism industry. It is alleged that terrorists were targeting Americans and nationals of those countries allied to America. In the process of carrying out their schemes, Kenya and the East African region has suffered in terms of losses incurred in the tourism and horticultural sectors. In some cases, potential investors are scared away. 
Referring to international terrorism and its impact on the lives of Africans, their property and general development matters, Professor Ali Mazrui once asserted that 'war and peace exist in Africa for reasons that are not always internal to Africa' (Mazrui 2003:8). The 1998 bombing in Nairobi saw 200 Kenyans perish. This was followed by another bombing in Mombasa in November 2001 with an Israeli hotel and chartered plane as targets. The plane was not hit but the hotel was bombed. The bombing killed three Israeli tourists and eleven Kenyans who were working at the hotel. The bombing generated a lot of debate but the most interesting was that of the American Embassy in Kenya. The Embassy complained that no arrests had been carried out by the Kenyan government yet US officials had 'intercepted communications among Al-Qaeda operatives in Eastern Africa and other unspecified intelligence indicating that terrorists were plotting an attack on embassies or the residences of foreign officials in Nairobi' (Mwangi 2003 a).

The American position was worsened by confirmation from the government of Kenya that security officers had identified a suspected AlQaeda member they believed was involved in both the 1998 and 2001 terrorist attacks. The Minister for Security issued an alert that an identified Al-Qaeda suspect, Fazal Abdalla Mohammed, had returned to Kenya. The unfolding story around terrorist threats and attacks led to the British and American embassies being closed down just after issuing travel advisories to their citizens against visiting the country and the region; and losses in the tourism and horticultural sectors.

The closing of the two foreign embassies was meant to force the Kenyan government to address the issue of international terrorism. On the other hand, the government demanded that America assist with funds to step up security. The American government responded positively and security was improved but the travel advisory was maintained. The British high commission lifted its travel advisory, including lifting the ban on British Airways. The lifting of the ban followed advice by UK intelligence that the threat to British interests in Kenya 'was not severe' (Mwangi 2003b:1). Other countries lifted travel advisories including Germany and France. The situation in the tourism industry became worse, to the extent that the Ministry began working on a plan to tap new markets in the Far East to make up for the losses.

The US pledged support for Kenya's economic recovery. This followed a request from Kenya's president, Mwai Kibaki, to the US for 30 billion Kenya Shillings for the fight against terrorism. 
The amount was arrived at after calculating the losses accrued due to a slump in tourism and horticultural exports. Chris Murungaru estimated that Kenya was losing \$14 million (about I billion Kenya shillings) a week in tourism earnings and tax revenues as a result of US and British warnings of a looming attack (Kelly 2003). According to statistics given by the Managing Director of the Kenya Airports Authority, during a seminar on security held at Jomo Kenyatta International Airport, there was a loss of 40 million Kenya shillings. The plea was delivered to the US by Kenyan Ministers, Chris Murungaru, Raila Odinga, John Michuki and Mukhisa Kituyi. The US congress was pleased with Kenya's efforts to fight terrorism and said 'it was a good example to other countries in the region' (Mwangi 2003 b: 1).

Many Kenyans did not take the travel advisory bans lightly. They said there was ill intention in the move because the British Prime Minister, Tony Blair, had travelled to New York just after the terrorists had bombed the Twin Towers. America was more unsafe than Somalia then. Despite this, Blair encouraged Britons to visit New York. Others cited the Israeli case saying that Kenya was far safer than Israel yet many Britons and Americans travelled there.

The issue seemed at first to affect Kenya, and later became an East African Regional concern prompting the three heads of state of the East African sub-region to issue a joint communiqué in which they said that the region was safe for tourists and investors and called for the removal of all travel bans. The leaders were attending the second extraordinary summit of the East African Community in Nairobi. The three heads of state of the East African Community decried that 'all travel advisories seriously impacted on the economies of the partner states of East Africa, particularly the tourism industry' (Juma 2003:1).

Kenyan authorities issued a statement about an eminent terrorist threat that came to affect the whole region and, when they sought to be compensated, they did not include in the compensation the losses that Uganda and Tanzania had recorded. This was contrary to what the treaty stipulated. In the Treaty establishing the East African Community, tourism is properly identified as an important component of development in each of the three East African Community countries. In Chapter 20, Article 115, section 1 and 3, it is stated that:

The partner states undertake to develop a collective and coordinated approach to the promotion and marketing of quality tourism into and within the community. To this end, the partner states shall coordinate 
their policies in the tourism industry and undertake to establish a framework of cooperation in the sector that will endure equitable distribution of benefits. The partner states undertake to develop a regional strategy for tourism promotion whereby individual efforts are reinforced by regional action (East African Secretariat 1999).

There was, in addition, a clause in the treaty which required that the three partner states approach the issue of terrorism together. This is important because strengthening security in Kenya alone can make terrorists resort to Uganda or Tanzania and their activities will affect tourism in the region.

With regard to regional security. Chapter 23, Article 124, section 1 and 6 states that:

The partner states agree that peace and security are pre-requisites to social and economic development within the community and vital to the achievement of the objectives of the community. In this regard, the partner states agree to foster and maintain an atmosphere that is conducive to peace and security through cooperation and consultations on issues pertaining to peace and security of the partner states with a view to prevention, better management and resolution of disputes and conflicts between them. The partner states undertake to cooperate in reviewing the region's security particularly on the threat of terrorism and formulate measures to combat terrorism (East African Secretariat 1999).

From the foregoing, we make observations to the effect that Kenya is not observing the East African Treaty to the letter. Kenya did not consult the other three East African States before issuing a security alert yet it was required to. This in turn led to a slump in tourism in the region. When it pursued compensation from America, it did not include losses incurred by its sister states in the region. In addition, it has failed to include the other states in its call to the US to help bolster internal security, especially at airports.

\section{Conclusion}

Africa can no longer rely on neo-liberal development policies advanced and funded by international lending agencies as they have failed to pull Africa out of its economic stagnation. These policies have been adequately criticized and new 'home grown' development measures have been called for. These new measures for Africa's development are already being put in place such as sub-regional cooperation. 
However, it should be noted that pursuit of 'home-grown' development policies are subject to international happenings. African countries have been caught up in the international order and disorder not by their own choice but by conquest and manipulation. Africa's integration in the world economic order and disorder complicates both nationstate, and regional or sub-regional order. One such case has been evident in the way the War on Terror has affected East Africa's tourism industry.

Countries in the East African region should fight terrorism collectively for the region's good rather than for individual nation-state benefits. This will minimize competition for handouts from either America or terrorist sponsoring states as well as militate against possible suspicion and mistrust between and among them. My call to East African leaders is that they should take part in fighting international terrorism and at the same time participate in peace building by addressing the root causes of these wars, especially in the Middle East.

\section{References}

Bolton, J. R., 2002, 'The New Strategic Framework: A Response to 21 st Century Threats' In U.S. Foreign Policy Agenda, Vol.7 No. 2, July pp.5-6.

Bush, G. W., 2002, Remarks at West Point, In U.S. Foreign Policy Agenda, 7, 2, July, pp. 2-6.

Chacha, B. K., 2003, 'From Local Conflicts to Global Terrorism: Can Refugees and Regional Security Problems Jeopardize the Renewal of Kenya', Paper presented at East African Sub-Regional Conference, Addis Ababa, Ethiopia, 30-3 I October.

East African Secretariat, 1999, The Treaty for the Establishment of the East African Community, Arusha: East African Secretariat.

Haynes, J., 2003, 'Religion and Politics: what is the impact of September 11?', Contemporary Politics: New Agendas and Debates, Vol. 9 No. 1, pp. 7-15.

Huntington, S., 1993, 'The Clash of Civilizations?', Foreign Affairs Vol. 72, No. 3, pp. 22-49.

Juma, L., 2003, 'E.A. Leaders Declare Region Safe For Tourists', The Daily Nation, 21 June, pp. 1.

Kelly, K. J., 2003, 'Kenya Seeks Shs. 30b from US: Aid Meant to Offset Economic Losses as a Result of Terrorism Threats', in The Daily Nation 26 June, pp.3.

Mazrui, A., 2003, 'Why Perish in Other People's Wars?' in The Daily Nation 1 April, pp. 8.

Mwangi, M., 2003a, 'US Military Spy Agency Raises Terror Alert Status', The Daily Nation, June 22, pp.2. 
Mwangi, M., 2003b, 'UK Lifts Flights and Travel Ban to Kenya and US backs Kibaki Plea for Cash to fight Terrorism', The Daily Nation, 27 June, pp. 1 \& 12.

Okoth, P. G., 2001, 'Africa in the International System Characterized by Globalization' Paper presented at the Regional Conference of the Kenya-America Studies Association at Egerton University, Kenya, August 12-17.

Okoth, P.G., 1996, 'Uganda's Relationship with the OAU., 1963-1994' in Transafrican Journal of History, Vol.25, 1996.

Omondi, C., 2003, 'Why US is Giving Sudan a Fresh Look', The Daily Nation, 24 October 2003. pp. 11

Ouma, J.P.B.M., 1970, Evolution of Tourism in East Africa (1900-2000), Nairobi: East African Literature Bureau.

Uche, C., 2002, 'Can African Countries Finance African Development? Evidence from the ECOWAS Fund', Paper presented at a conference 'Africa and the Development Challenges of the New Millennium' in Accra Ghana, 23 $3^{\text {rd }}-26^{\text {th }}$ April.

Venter, D., 1997, 'Africa and the New World Order: from Marginalisation to Regeneration?' in N.N. Vohra and K. Mathews, eds., Africa, India and South-South Cooperation, New Delhi: Har-Anand Publications, 1997.

Wolf, J. S., 2002, 'US Approaches to Non-Proliferation' in U.S. Foreign Policy agenda, Vol.7 No. 2, pp. 7-10. 
